\title{
Sulama Suyu Tuzluluğu ve Yıkama Gereksinimi Oranlarının Yoncada Çimlenme ve Gelișmeye Etkisi
}

\author{
Tuğba YETER ${ }^{*}$ \\ Engin YURTSEVEN ${ }^{2}$
}

'Toprak Gübre ve Su Kaynakları Merkez Araștırma Enstitüsü Müdürlüğü, ANKARA

${ }^{2}$ Ankara Üniversitesi Ziraat Fakültesi Tarımsal Yapılar ve Sulama Bölümü, ANKARA

*Sorumlu yazar, e-posta (Corresponding author, e-mail): tugba@tgae.gov.tr

Geliș tarihi (Received) : 04.02.2015

Kabul tarihi (Accepted) : 25.03.2015

\section{Öz}

Bu çalıșma, farklı tuzluluktaki sulama sularının değișik yıkama gereksinimleri ile uygulanması durumunda yoncada çimlenmeye ve ilk gelișmeye olan etkilerini incelemek amacıyla lizimetre koșullarında altı ay süreyle yürütülmüștür. Araștırma, 3 farklı sulama suyu tuzluluğu (0.25 dS m-1, $1.5 \mathrm{dS} \mathrm{m}^{-1}$ ve $\left.3.0 \mathrm{dS} \mathrm{m}^{-1}\right)$ ile 4 yıkama gereksinimi (\%10,\%20, \%35 ve \%50) konuları için 3 tekrarlamalı olarak, tesadüf bloklar deneme desenine göre yürütülmüștür. Bitki yaș ağırlığı (verim) ve kuru ağırlığı (biokütle) değerleri elde edilerek değerlendirilmiștir. Elde edilen sonuçlar bitki verimi üzerine, hem sulama suyu tuzluluğu, hem de yıkama gereksinimi düzeylerinin etkili olduğunu, biokütle değerleri üzerine ise sadece yıkama düzeyinin önemli etkide bulunduğunu ortaya koymuștur. En fazla verim; tuzluluk konuları içerisinde $1.5 \mathrm{dS} \mathrm{m}^{-1}$ tuzluluk düzeyinde, yıkama konuları içerisinde ise \%50 yıkama gereksinimin uygulandığı konuda elde edilmiștir.

Anahtar Kelimeler: Sulama, sulama suyu kalitesi, yıkama gereksinimi, yonca

\section{The Effects of Irrigation Water Qualıty and Leachıng Requirements on Germination and Vegetatif Growth of Alfalfa}

\section{Abstract}

This study was conducted to determine the effects of different irrigation water salinity and leaching rates over germination and initial growth of clover. Experiment were carried out in the lysimeter conditions for six months. The three different irrigation water salinity levels $\left(0.25 \mathrm{dS} \mathrm{m}^{-1}, 1.5 \mathrm{dS} \mathrm{m}^{-1}\right.$ ve $\left.3.0 \mathrm{dS} \mathrm{m}^{-1}\right)$ and the four leaching rates (10\%, 20\%, 35\% and 50\%) were used in randomized block design with three replications. Plant fresh weight (yield) and dry weights (biomass) were measured to evaluate the impacts of irrigation water salinity and leaching rates. It was observed that both irrigation water salinity and leaching rates had significant impacts on yield and leaching rates had significant effects over biomass. The highest yield was obtained from the treatment with $1.5 \mathrm{dS} \mathrm{m}^{-1}$ salinity level and $50 \%$ leaching rate.

Key Words: Irrigation, irrigation water quality, leaching requirement, alfalfa

\section{Giriș}

Tarımsal üretimde yeterli miktar ve kalitede sulama suyunun doğadan temini gün geçtikçe zorlașmaktadır. Özellikle kurak ve yarı kurak bölgelerde, sulu tarım için doğal kaynakların azalması veya kirlenmesi, düșük kaliteli sulama suyu ile tarım yapmak zorunda kalınması, genellikle üretimin yapıldığı bölgelerdeki toprakların

tuzlanmasına ve üretim dıșı kalmasına neden olmaktadır. Genel olarak yapılan çalıșmalar, yersel olarak, tuzluluğu yüksek sulama sularının tarımsal amaçla bazı șartların yerine getirilmesi ve gerekli teknik önlemlerin alınmasıyla kullanılabilir hale gelebildiklerini de göstermektedir. 
Ayyıldız (1976), tuz kapsamı yüksek sayılan sulama sularının, uygun aralıklarla ve bitki kök bölgesindeki fazla tuzları yıkayacak miktarda verilmesiyle, bu suların sulamada kullanımasının mümkün olduğunu belirtmiștir. Ayrıca toprak ve bitki koșullarının farklılığı nedeniyle aynı kalitedeki sulama sularının farklı topraklarda farklı etkiler yapacağı, hatta aynı toprak koșullarında bile sulama uygulamaları ve drenaj koșullarının farklı olması nedeniyle farklı etkiler yapacağını ve bunun en iyi kanıtının ise sulama suyu sınıflandırımasında ortaya çıktığını ifade etmiștir. Buna göre sorunlu ve zararlı olarak sınıflandırılan bir suyun, bașka bir sınıflandırmada kullanılabilir sınıfa girdiğini bildirmiștir. Rizk vd., (1978), üç yonca türünde $0.01 \mathrm{~N}, 0.02 \mathrm{~N}$ ve $0.1 \mathrm{~N} \mathrm{NaCl}$ ve $\mathrm{CaCl}_{2}$ konsantrasyonlarının çimlenme oranı, çimlenme indeksi, fide boyu ve kuru ağırlık artıșında, artan konsantrasyonların bu özellikleri olumsuz yönde etkilediğini belirlemișlerdir. Çalıșmada $\mathrm{CaCl}_{2}$ 'ün olumsuz etkisinin NaCl'e göre daha düșük düzeyde olduğunu tespit etmișlerdir. Hamdy (1988), tuzlu sulama suyu uygulanması durumunda tuza dayanıklığı farklı olan bitkilerden 10'unun çimlenme oranlarını test etmiștir. Arpa, buğday ve mısırın artan tuzlulukta çimlenme oranında en az düșüș gösteren bitkiler olduğu görülmüș, 16 dS/m olan en yüksek tuzlulukta bile tohumların yarısından fazlasının çimlendiği belirlenmiștir. Mısır, buğday ve arpadan sonra tuza dayanımda 3. sırada yer almıștır. Araștırmacı ayrıca $4 \mathrm{dS} \mathrm{m}^{-1}$ ye kadar olan tuzlu suların çimlenmede bir azalma olmadan dayanıklı ve yarı dayanıkı bitkilerin sulanmasında güvenle kullanılabileceğini belirtmiștir.

Yurtseven vd., (1995) domateste çimlenme üzerine tuzluluğun önemli düzeyde etki yaptığını ve gerek tuzluluk, gerekse SAR düzeylerinin artmasıyla çimlenen tohum sayılarında azalma olduğunu, 10-11 dS $\mathrm{m}^{-1}$ üzerindeki tuzluluk düzeyinde çimlenmenin olmadığını belirlemișlerdir. Fide gelișiminde ise $4 \mathrm{dS} \mathrm{m}^{-1}$ üzerindeki tuzluluk düzeyleri olumsuz etki yapmıștır. Yurtseven vd., (1996), biber bitkisinde $3 \mathrm{dS} \mathrm{m}^{-1}$ tuzluluk düzeyinin çimlenme üzerine etkili olmadığını ve fide boylarında tuzluluğun artması ile yaklașık \%13 kadar bir artıș olduğunu belirlemișlerdir. Yurtseven vd., (1997) marul bitkisinin tuza orta hassas ve $\mathrm{EC}_{\mathrm{w}}$ değerinin $2 \mathrm{dS} \mathrm{m}^{-1}$ düzeyinden büyük olması durumunda, bitki yaș ağırlığında önemli bir azalma olmadığını tespit etmișlerdir. Ayrıca toprak nem düzeyinin sık sulamalarla yüksek tutulması ile bitkide verim artıșı sağlanırken, bitkinin toplam kül miktarı yani mineral madde içeriğinin sulama suyu tuzluluğunun artıșı ile yükselme gösterdiğini belirlemișlerdir.

Genellikle üst toprak (tohum yatağı) tuzluluğu 4 dS $\mathrm{m}^{-1}$ 'den büyükse çimlenme ve erken ekimde gelișme durur veya geriler. Yavaș çimlenme daha sonra toprağın kabuk bağlamasını ve bitki gelișimini azaltarak hastalıkların olușumunu teșvik eder ve çıkıșı geciktirir. Yağıș veya ekim öncesi sulama, tuzluluğun düșmesine ve kabuk bağlamanın gecikmesine yardım ederek iyi bir çıkıș sağlayabilir (Kanber vd., 1992). Yurtseven vd., (2000), brokolide çalıștıkları tuzluluk düzeyleri için, tuzluluğun artması ile bitkide biyokütle üretiminin azaldığını ve bu azalmanın bașladığı düzeyin 5.78 dS $\mathrm{m}^{-1}$ olduğunu belirlemișlerdir. Ayrıca sulama suyu tuzluluğunun artmasına paralel olarak toplam kül değerinin de arttığını gözlemlemișler ve tuzluluğunun 0.25 dS $\mathrm{m}^{-1}$ olduğu kontrol düzeyinde toplam kül değeri \%22.35 iken, 9.38 dS $\mathrm{m}^{-1}$ tuzluluk düzeyinde ise bu değerin \%51.8 olduğunu ve bu farklılığın ise $1.5 \mathrm{dS} \mathrm{m}^{-1}$ tuzluluk düzeyinden itibaren bașladığını gözlemlemișlerdir. Bitkide verim değerinin ise sulama suyu tuzluluğunun artmasıyla azalma gösterdiğini saptamıșlar ve bu azalmanın bașladığı tuzluluk düzeyini $3.5 \mathrm{dS} \mathrm{m}^{-1}$ olarak ölçmüșlerdir. Tuzluluk

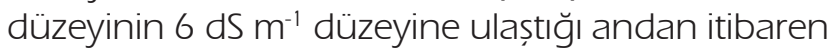
ise verimde önemli azalmalar olușmaya bașladığını gözlemlemișlerdir.

Bu çalıșma, yoncada farklı tuzluluktaki sulama sularının değișik yıkama gereksinimleri ile uygulanması durumunda, çimlenmeye ve ilk gelișmeye olan etkilerini incelemek amacıyla yürütülmüștür. Bu șekilde değișik tuzluluktaki sulama sularının çimlenmeye ve ilk gelișme döneminde bitkiye olan etkilerinin farklı yıkama gereksinimleri ile uygulanması halinde nasıl bir değișim göstereceği ve düșük kaliteli tuzlu suların sulamada kullanım olanakları araștırılmıștır.

\section{MATERYAL ve YÖNTEM}

\section{Materyal}

Çalıșmada Bilensoy 80 yonca çeșidi kullanılmıștır. Denemenin yapıldığı bölgede yıllık sıcaklık ortalaması $11.6{ }^{\circ} \mathrm{C}^{\prime}$ dir. Ortalama minimum sıcaklık ocak ayında $-2.9^{\circ} \mathrm{C}$, ortalama maksimum sıcaklık temmuz ayında $30^{\circ} \mathrm{C}$ 'dir. Ankara'nın yıllık ortalama yağıș miktarı ise 396.6 mm' dir.

Deneme toprağının bünyesi kumlu-tınlı-kil 
(SLC) olarak belirlenmiștir. Yapılan laboratuvar analizlerinde $\mathrm{pH}$ değeri 8.18, EC değeri 0.19 dS $\mathrm{m}^{-1}$ olarak bulunmuștur (Çizelge 1 ).

Araștırmada üç farklı tuzluluk düzeyine sahip
Sulamalarda kullanılan sular plastik bidonlar içerisinde hazırlanmıș ve Șekil 1' de görüldüğü gibi, damla sulama sistemi yardımıyla kolonlara uygulanmıștır. Kolonlardaki nem düzeylerini izlemek için 0-30 cm derinliğe TDR probları yerleștirilmiștir.

Çizelge 1. Deneme toprağına ait fiziksel ve kimyasal analiz bulguları

Table 1. Physical and chemical analysis results of soils

\begin{tabular}{|c|c|c|c|c|c|c|c|c|}
\hline $\begin{array}{c}\text { Org. } \\
\text { Madde \% }\end{array}$ & \multicolumn{2}{|c|}{$\begin{array}{c}\text { Nem } \\
\%\end{array}$} & $\mathrm{pH}$ & $\begin{array}{c}E C \\
\left(\mathrm{dS} \mathrm{m}^{-1}\right)\end{array}$ & $\begin{array}{c}\text { Tarla } \\
\text { Kapasitesi } \\
\%\end{array}$ & \multicolumn{2}{|c|}{$\begin{array}{c}\text { Solma } \\
\text { Noktası } \\
\%\end{array}$} & $\begin{array}{l}\text { Toprak } \\
\text { Bünyesi }\end{array}$ \\
\hline 1.33 & \multicolumn{2}{|c|}{2.12} & 8.18 & 0.19 & 16.04 & \multicolumn{2}{|c|}{8.23} & SLC \\
\hline \multicolumn{5}{|c|}{ KATYONLAR (me/l) } & \multicolumn{4}{|c|}{ ANYONLAR (me/l) } \\
\hline $\mathrm{Na}^{+}$ & $\mathrm{K}^{+}$ & $\mathrm{Ca}^{++}$ & $\mathrm{Mg}^{++}$ & $\begin{array}{l}\text { Toplam } \\
\left(\mathrm{me} \mathrm{I}^{-1}\right)\end{array}$ & $\mathrm{HCO}_{3}^{-}$ & $\mathrm{Cl}^{-}$ & $\mathrm{SO}_{4}=$ & $\begin{array}{l}\text { Toplam } \\
\left(\text { me l }^{-1}\right)\end{array}$ \\
\hline 0.52 & 0.17 & 1.08 & 0.8 & 2.57 & 1.18 & 0.6 & 0,79 & 2,57 \\
\hline
\end{tabular}

sulama suyu kullanılımıștır $\left(\mathrm{T}_{1}=0.25\right.$ (șebeke suyu), $\mathrm{T}_{2}=1.5, \mathrm{~T}_{3}=3.0 \mathrm{dS} \mathrm{m}^{-1}$ ). Sulama suları, SAR değeri, $<$ 1 olacak șekilde hazırlanmıștır. Denemede kullanılan suların kimyasal özellikleri Çizelge 2'de verilmiștir.
Yonca tohumları Mayıs ayı ortalarında yetiștirilmiș ve fideler 3-4 yapraklı olduklarında lizimetrelere șașırtılmıșlardır. Fideler birkaç kez șebeke suyu ile sulandıktan sonra konuların uygulanmasına geçilmiștir. Sulamalar tüm konularda aynı zamanda

Çizelge 2. Denemede kullanılan suların kimyasal özellikleri

Table 2. Chemical analysis results of irrigation waters

\begin{tabular}{|c|c|c|c|c|c|c|c|c|c|c|c|c|}
\hline \multirow{2}{*}{ 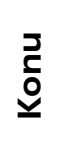 } & \multirow[b]{2}{*}{ PH } & \multirow{2}{*}{ שَ } & \multicolumn{5}{|c|}{ Katyonlar } & \multicolumn{4}{|c|}{ Anyonlar } & \multirow{2}{*}{$\frac{\tilde{\sigma}}{\tilde{s}}$} \\
\hline & & & $\mathrm{Na}^{+}$ & $\mathrm{K}^{+}$ & $\mathrm{Ca}^{+2}$ & $\mathrm{Mg}^{+2}$ & $\begin{array}{l}\text { Top. } \\
\text { me }\left.\right|^{-1}\end{array}$ & $\mathrm{HCO}_{3}{ }^{-}$ & $\mathrm{Cl}^{-}$ & $\mathrm{SO}_{4}^{-2}$ & 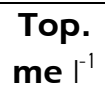 & \\
\hline$T_{1}$ & 7.2 & 0.28 & 0.46 & 0.07 & 1.23 & 0.58 & 2.34 & 1.60 & 0.52 & 0.22 & 2.34 & 0.48 \\
\hline$T_{2}$ & 7.0 & 1.55 & 2.54 & 0.53 & 10.85 & 3.40 & 17.32 & 6.80 & 9.43 & 1.09 & 17,32 & 0.95 \\
\hline$T_{3}$ & 6.9 & 3.05 & 3.70 & 0.78 & 21.98 & 5.56 & 32.02 & 11.3 & 17.78 & 2.94 & 32,02 & 0.99 \\
\hline
\end{tabular}

Denemede bitki yetiștirme ortamı olarak PVC borulardan kesilerek olușturulan, $65 \mathrm{~cm}$ yüksekliğinde ve $35 \mathrm{~cm}$ çapında lizimetreler kullanılmıștır. Denemelerde ayrıca, damla sulama lateralleri, toprak nemindeki değișim izlendiği TDR (Trace) aleti, EC metre(YSI 3200), pH metre (MI 151), kurutma firını, hassas terazi ve drenaj suyu kimyasal analizlerinin yapıldığı iyon kromatografisi (DIONEX 1600) cihazları kullanıımıștır.

\section{Yöntem}

Çalıșma, 3 sulama suyu kalitesi ile 4 yıkama hacmi konusunun tesadüf parsellerinde faktöriyel düzende 3 tekrarlamalı olarak uygulandığı, toplamda 36 adet lizimetrede yürütülmüștür. Sulama suyu kalitesi olarak 3 konu $\left(T_{1}=0.25, T_{2}=1.5\right.$, $\left.\mathrm{T}_{3}=3.0 \mathrm{dS} \mathrm{m}^{-1}\right)$, ylkama hacmi olarak ise $\left(Y_{1}=\% 10\right.$, $\left.Y_{2}=\% 20, Y_{3}=\% 35, Y_{4}=\% 50\right) 4$ konu ele alınmıștır. yapılmıștır. Uygulanan sulama suyu miktarı ise, tuzluluk ve yıkama gereksinimi konularına göre farkllık göstermiștir. Bitki gelișme dönemi içerisinde gerektiğinde bitki koruma amaçlı mücadele yapılmıștır.

Denemede kullanılan sulama sularında ve elde edilen drenaj sularında anyon $\left(\mathrm{Cl}-, \mathrm{NO}_{2}{ }^{-}, \mathrm{NO}_{3}{ }^{-}\right.$, $\left.\mathrm{SO}_{4}{ }^{-2}\right)$ ve katyon $\left(\mathrm{Na}^{+}, \mathrm{K}^{+}, \mathrm{Ca}^{+2}, \mathrm{Mg}^{+2}\right)$ analizleri yapılmıștır. EC ve pH değerleri Richards (1954) de belirtildiği gibi cam elektrodlu EC metre ile (YSI 3200) ve $\mathrm{pH}$ metre ile (Ml 151 model) yapılmıștır. Anyon ve katyon analizleri ise iyon kromatografisi ile (DIONEX 1600S) ile yapılmıștır (Anonymous, 1993). 


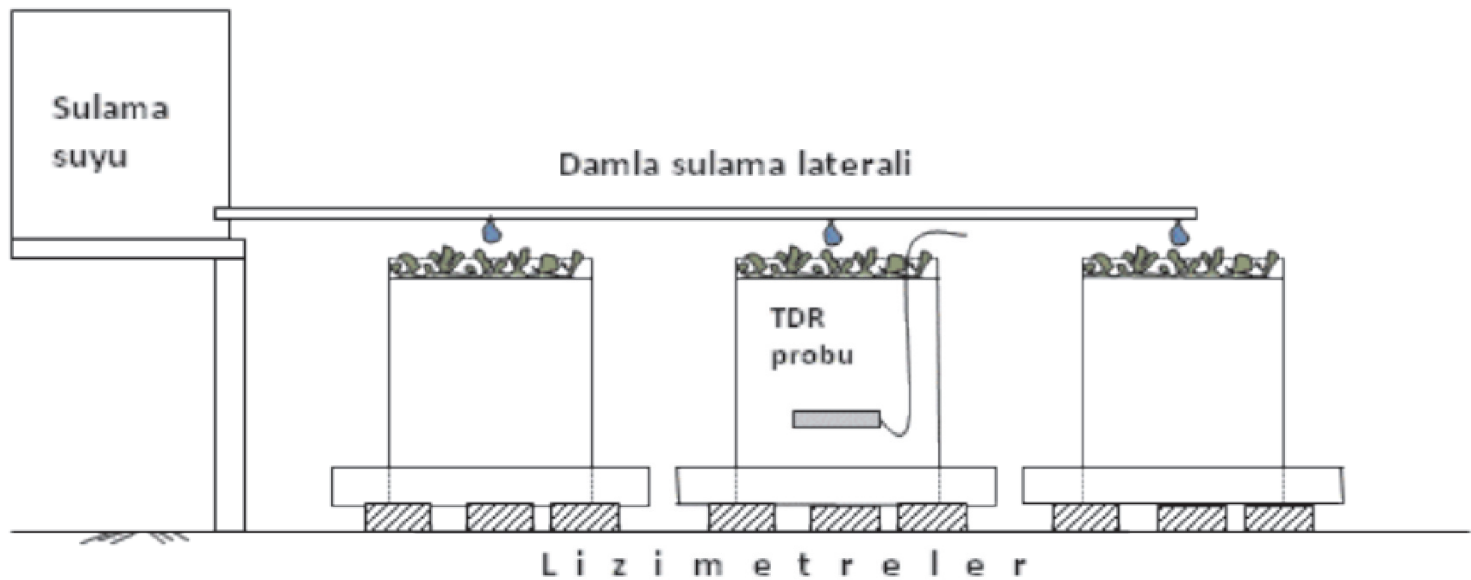

Sekil 1. Deneme düzeni

Figure 1. Experimental design

\section{Bulgular ve Tartıșmalar}

Bu çalıșmadan elde edilen veriler kolonlardaki toprak tuzluluklarının, bitki yaș ve kuru ağırlıklarının ve yıkama intiyacı uygulanan konularda drenaj sularının kalitelerinin değișimlerinin incelenmesi șeklinde değerlendirilmiștir.

Denemeler sonunda lizimetrelerden yaklașık 40 cm derinlikten toprak örnekleri alınarak laboratuvar analizleri yapıımıștır. Buna göre toprağın bașlangıç tuzluluk değerleri ile konuların uygulanması sonucunda elde edilen tuzluluk değerleri karșılaștırımıștır. Uygulanan sulama sularının tuzluluk düzeylerine ve yıkama intiyacı uygulamalarına bağlı olarak tuzluluklar farklıık göstermiștir. Șebeke suyunun uygulandığı $T_{1}$ konusunda saturasyon ekstraktı EC değerleri, yıkamanın uygulandığı $Y_{1}, Y_{2}, Y_{3}$ ve $Y_{4}$ konularında sırasılyla $0.88,0.50,0.35$ ve $0.28 \mathrm{dS} \mathrm{m^{-1 }}$ olarak elde edilmiștir. $T_{2}$ konusunun uygulandığı konuda ise EC değerleri yıkama konularına göre sırasıyla 0.85 , $0.62,0.42$ ve $0.38 \mathrm{dS} \mathrm{m}^{-1}$ bulunmuștur. $\mathrm{T}_{3}$ konusunda da uygulanan yıkama konularına göre $2.35,1.60,1.48$ ve $0.86 \mathrm{dS} \mathrm{m}^{-1}$ olarak elde edilmiștir. Uygulanan tuzluluk düzeylerinin artmasıyla toprak tuzlulukları artarken, yıkama oranlarının artması ile azalma göstermiștir. Artan sulama suyu tuzlulukları etkisinde toprakta biriktirilen toplam tuz miktarlarında artma görülürken, daha fazla yıkama suyu uygulanması ile tuzların yıkanma oranları artmıș ve sonuçta toprak tuzlulukları azalmıștır. Uygulanan tuzluluk düzeylerinin artmasıyla toprak tuzlulukları artarken, yıkama oranlarının artması ile azalma göstermiștir.
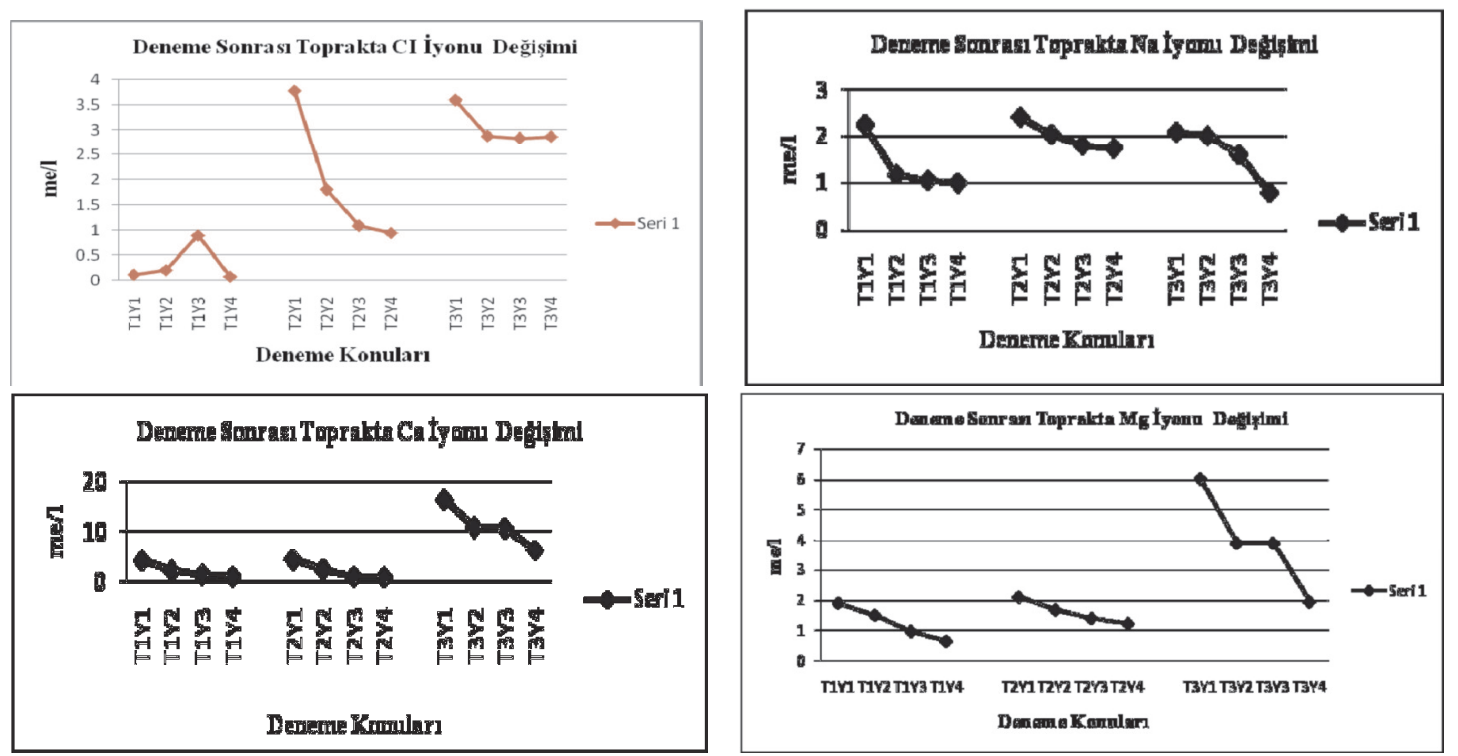

Sekil 2. Deneme topraklarında bazı iyonlarının konulara göre değișimi.

Figure 2. Change according to the subject of some ions in the experimental soils 
Șekil 2' nin ncelenmesinden anlașılacağı üzere, topraktaki Ca, Mg, Na ve Cl konsantrasyonları yıkama oranının artmasına bağlı olarak azalma eğilimi göstermiștir. Artan sulama suyu tuzlulukları etkisinde toprakta biriktirilen toplam tuz miktarlarında artma görülürken, daha fazla yıkama suyu uygulanması ile tuzların yıkanma oranları artmıș ve sonuçta toprak tuzlulukları azalmıștır.

Denemelerde elde edilen drenaj suyu tuzluluk (EC) değerleri incelendiğinde; uygulanan konulara göre değiștiği gözlenmiștir (Șekil 3 ve 4). Drenaj suyu tuzlulukları sulama suyu tuzluluklarının artması ile artmıș, yıkama oranlarının artması ile ise azalmıștır.

Her sulama sonrası alınan drenaj sularında EC değerleri sulamada kullanılan suyun kalitesi ve yıkama oranına göre değișmiștir. $T_{1}, T_{2}$ ve $T_{3}$ konularında yıkamayla beraber drenaj sularında EC değerinin giderek azalmıștır. Buna göre uygulanan sulama suyunun EC değeri ve yıkama oranları drenaj sularının EC değerinde farklılığa neden olmuștur.

Sulama periyodu boyunca drenaj sularının elektriksel iletkenlik değerleri ve içerdiği iyonların miktarı hem tuzluluk konuları hem de yıkama konuları ile etkileșim içerisindedir. Sulama suyu tuzluluğu arttıkça, elektriksel iletkenlik değeri ve içerdikleri iyonların miktarı artmaktadır. Ancak sulama

Illk Sulama

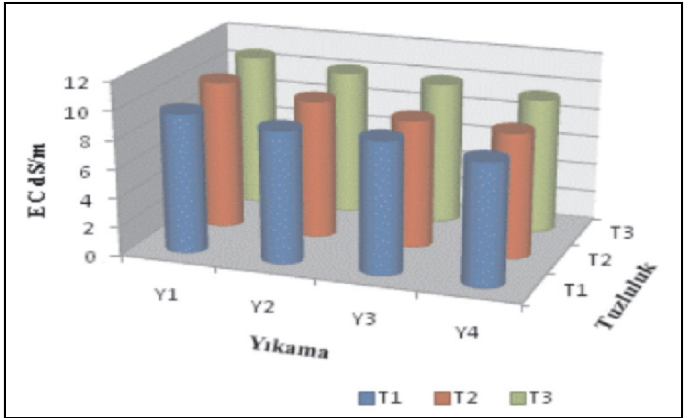

suyu ile birlikte uygulanan yıkama oranları arttıkça, drenaj sularının elektriksel iletkenlik değeri ve içerdiği iyonların miktarı azalma göstermektedir.

Araștırmada her üç sulamada bir 13., 6. ve 9. sulama) drenaj sularının EC değerleri incelenmiștir. Buna göre yapılan varyans analizi sonuçlarında, EC değerleri arasındaki ilișki \%1 önem seviyesinde istatistiksel açıdan önemli bulunmuștur. Diğer bir deyișle, gerek tuz konsantrasyonu gerek yıkama oranları ve gerekse bunların interaksiyonu istatistiksel açıdan önemlidir. Sulama suyu tuz konsantrasyonu arttıkça artan tuzlulașma yıkama oranın artmasıyla önemli bir azalma göstermiștir. Özellikle $Y_{4}$ konusu olan \%50 yıkama oranı tüm tuzluluk düzeylerinde toprakta deneme bașındaki toprak tuzluluğunun en fazla azalmasını sağlamıștır.

Deneme süresince yonca iki kez hasat edilmiștir. Hasat edilen bitkilerde yaș ve kuru ağırlık (biyokütle) değerleri incelenmiștir (Çizelge 3). Yaș ağırlıklar en düșük $T_{3} Y_{2}(52.9 \mathrm{~g})$, en yüksek $T_{2} Y_{3}$ konusundan $(117.1$ g) elde edilmiștir. Biyokütle değerlerinde ise en düșük değer $T_{3} Y_{1}$ (33.5 g), en yüksek değer ise $\mathrm{T}_{2} \mathrm{Y}_{4}$ konusundan (83.1 g) elde edilmiștir. Bitki yaș ağırlıkları sulama suyu tuzluluğunun artması ile azalırken, yıkama oranlarının artması ile artma göstermiștir.

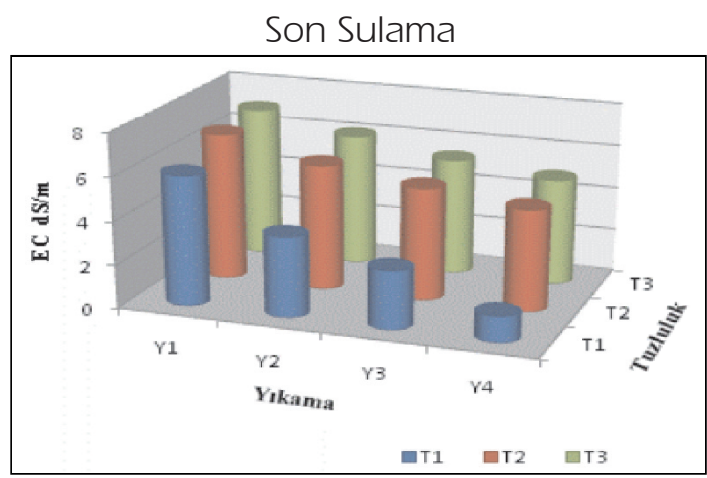

Șekil 3. İlk ve son sulama sonrası drenaj suyu EC değișimi

Figure 3. After the first and last irrigation drainage water EC change
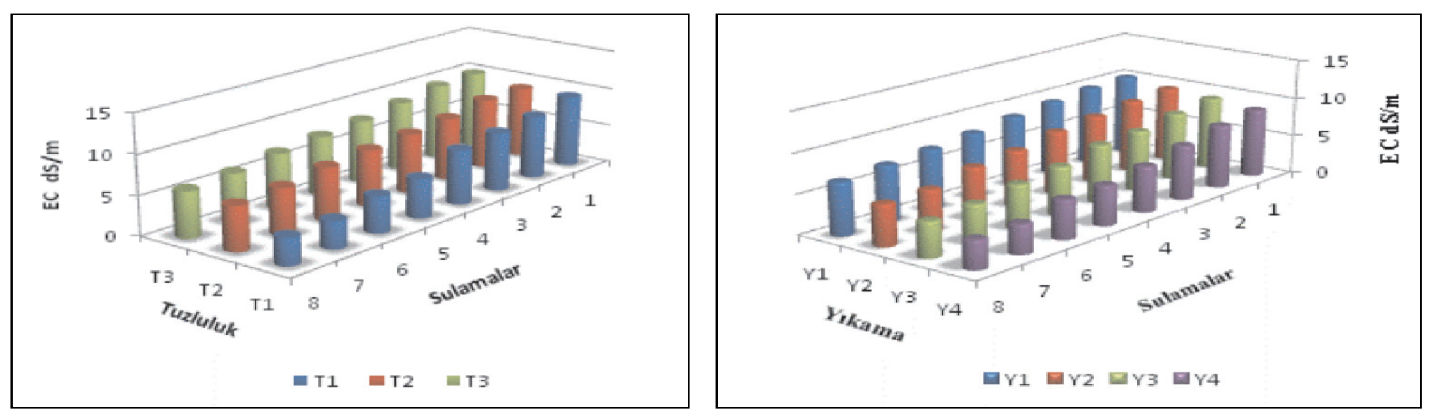

Șekil 4. Tuzluluk ve yıkama konuları için ortalama drenaj suyu EC değișimi

Figure 4. Salinity and washing threads for average drainage water in EC change 
Çizelge 3. Yoncada ortalama yaș ve kuru ağırlık değerleri

Table 3. The average of wet and dry weight values for alfalfa

\begin{tabular}{|c|c|c|}
\hline Konu & Yaș Ağırlık (g) & Kuru Ağırlık (g) \\
\hline $\mathrm{T}_{1} \mathrm{Y}_{1}$ & 74.20 & 51.00 \\
\hline $\mathrm{T}_{1} \mathrm{Y}_{2}$ & 89.30 & 71.00 \\
\hline $\mathrm{T}_{1} \mathrm{Y}_{3}$ & 104.80 & 60.20 \\
\hline $\mathrm{T}_{1} \mathrm{Y}_{4}$ & 85.70 & 59.20 \\
\hline $\mathrm{T}_{2} \mathrm{Y}_{1}$ & 85.30 & 59.80 \\
\hline $\mathrm{T}_{2} \mathrm{Y}_{2}$ & 91.30 & 65.90 \\
\hline $\mathrm{T}_{2} \mathrm{Y}_{3}$ & 117.10 & 74.10 \\
\hline $\mathrm{T}_{2} \mathrm{Y}_{4}$ & 116.10 & 83.10 \\
\hline $\mathrm{T}_{3} \mathrm{Y}_{1}$ & 59.20 & 33.50 \\
\hline $\mathrm{T}_{3} \mathrm{Y}_{2}$ & 52.90 & 46.10 \\
\hline $\mathrm{T}_{3} \mathrm{Y}_{3}$ & 68.80 & 55.80 \\
\hline $\mathrm{T}_{3} \mathrm{Y}_{4}$ & 108.60 & 80.00 \\
\hline
\end{tabular}

Ortalama yaș ağırlıklar sulama suyu tuzluluklarının $T_{1}$ den $T_{3}{ }^{\prime}$ e değișmesi ile 88.49 (AB), 102.49 (A) ve $76.52 \mathrm{~g}$ (B) olurken; yıkama oranlarının $Y_{1}$ den $Y_{4}{ }^{\prime}$ e değișmesi ile sırasıyla 72.91 $(B), 83.36(A B), 96.89(A B)$ ve $103.51 \mathrm{~g}(A)$ olarak elde edilmiștir. Tuz oranı bitki gelișimini geriletmekte, ancak artan yıkama oranı yaș ve kuru ağırlık değerlerinde artıș sağlamaktadır (Karakullukçu ve Adak, 2008). Biyokütle değerleri yıkama oranlarının artması ile önemli değișiklik göstermiș ve $Y_{1}$ den $Y_{4}^{\prime}$ e gidildikçe azalarak, sırasıyla șu değerler elde edilmiștir; 48.1 (B), 59.33 (AB), $63.37(A B)$ ve $74.15 \mathrm{~g}(\mathrm{~A})$. Elde ettiğimiz sonuçlar, Özdemir ve Engin (1994), Joaquin vd., (1982) ile Goertz ve Coons (1991) tarafından belirtilenlerle benzerlik göstermektedir.

\section{SONUC}

Araștırma, farklı kalitedeki sulama sularının değișik yıkama oranları ile uygulanması durumunda, yonca bitkisine, toprak profilindeki tuz değișimine ve drenaj suyu kalitesine etkilerini incelemek amacıyla yürütülmüștür. Elde edilen sonuçlara göre; farklı sulama suyu miktarının yoncada vegetatif gelișme üzerinde etkili olduğu, tuzluluk seviyesinin artması ile gelișmenin yavașladığı ve hasat sonrası alınan yaș ve kuru ağırık değerlerinin ise azaldığı belirlenmiștir. Ancak yıkama ile birlikte hem tuzluluk seviyesinde, hem de bitki yaș ve kuru ağırlık değerlerinde artıș olduğu görülmüștür.

Toprak tuzlulukları, sulama suyu tuzluluklarının artması ile artma göstermiștir. Bașlangıç toprağında ölçülen tuzluluk değeri 0.19 dS m²-1 iken, bu değer
$\mathrm{T}_{3}$ konusunda $2.35 \mathrm{dS} \mathrm{m}^{-1}$ olarak elde edilmiștir. Ayrıca yüksek tuzluluk seviyesi ile sulanan kolonlarda yıkama oranı arttıkça toprak tuzluluk değeri azalma eğilimi göstermiștir.

Yoncada yüksek verim ve biokütle elde edebilmek amacıyla sulama suyu tuzluluğu $1.5 \mathrm{dS}$ $\mathrm{m}^{-1}$ den yüksek olmayan sular kullanılmalıdır. Daha yüksek tuzlu suların kullanılması durumunda, verim ve biokütle azalmasını göz önüne alarak sulama suyuna ayrıca yıkama suyu eklenmelidir. Bunun dıșında yetiștiricilik yapılan toprağın kimyasal iyon içeriğine bakıldığında, toprak tuzluluğu düșük olduğunda, belli düzeylere kadar tuzluluklar bitki verimine katkı sağlayııı etkide bulunabilmektedirler.

\section{Teșekkür}

Bu calıșma Tuğba YETER tarafından Ankara Üniversitesi Fen Bilimleri Enstitüsü Tarımsal Yapılar Ve Sulama Ana Bilim Dalında yapılan yüksek lisans tezini kapsamaktadır.

\section{KAYNAKLAR}

Anonymous (1993). The determination of inorganic anions in water by ion chromatography; Method 300.0. U.S. Environmental Protection Agency, Cincinnati, Ohio.

Ayyıldız M (1976). Sulama suyu, sulama suyu kalitesi ve sulamada tuzluluk problemleri. A.Ü. Ziraat Fakültesi Yayınları. No.636, Ankara.

Goertz S H, Coons J M (1991). Tolerance of tepary and navy beans to $\mathrm{NaCl}$ during germination and emergence. Hort. Science 26 (3):246-249

Hamdy A (1988). Research work at Bari Institute for re-use of low quality water and its impact on soil and plants. International Seminar, 16-21 January, Egypt.

Joaquin S R, Dantur N C, Casanova M R, Bustos V N (1 982). Performance of soybean cV. Bragg under conditions of soil salinity in the field. Revista Industral Agricola de Tucumen. 31 (2):147-149.

Kamber, R, Kırda C, Tekinel O (1992). Sulama suyu niteliği ve sulamada tuzluluk sorunları C..̈̈. Zir. Fak. Yayınları. Genel Yayın No.21 Ders Kitabı. Yayın No.6., Adana

Karakullukçu E, Adak M S (2008). "Bazı nohut (Cicer arietinum L.) çeșitlerinin tuza toleranslarının belirlenmesi". Tarım Bilimleri Dergisi, Cilt No: 14, Sayı No:4, Ankara.

Özdemir S, Engin M (1994). Nohut (Cicer arietinum L.) bitkisinin çimlenme ve fide büyümesi üzerine $\mathrm{NaCl}$ konsantrasyonlarının etkisi. Turkish Journal of Agricultural and For. 18: 323-328.

Rizk T Y, Al Hasan A M, El Tekelt II R A, Alawı B J (1978). Effect of salinity on germination and seedling vigor of some annual medics Medicago spp. Mesopotamia Journal of Agriculture, 13(2): 105-121.

Scofield C S (1935). The salinity of irrigation water. Sinithsn. Inst. Ann. Rpt., 275-287, Illus. 
Shalhevet J, Kamburov J (1976). Irrigation and salinity worldwide survey. Int. Common Irrigation and Drainage. New Delhi, India.

Yurtseven E, Sönmez B (1995). Değișik tuzluluk ve SAR değerlerine sahip suların toprak tuzluluğu ile domates bitkisinin gelișimine ve verimine olan etkileri. Toprak ve Gübre Araș. Md. Yayınları, Genel Yay. No: 202, Ankara

Yurtseven E, Öztürk A, Kadayıfçı A, Ayan B (1996). Sulama suyu tuzluluğunun biberde (Capsicum annuum) farklı gelișme dönemlerinde bazı verim parametrelerine etkisi. A.Ü.Ziraat Fak. Tarım Bilimleri Dergisi, 2(2):5-9.
Yurtseven E, Bozkurt D O (1997). Sulama suyu kalitesi ve toprak nem düzeyinin marulda verim ve kaliteye etkisi. A.Ü.Ziraat Fak. Tarım Bilimleri Dergisi, 3(2).

Yurtseven E, Baran H Y (2000). Sulama suyu tuzluluğu ve su miktarının brokolide (Brassica oleracea botrytis) verim ve mineral madde içeriğine etkisi. Doğa Tr. J. Agric. For., 24:185-190. 